\title{
PENGARUH BIAYA PROMOSI DAN BIAYA TENAGA KERJA TERHADAP PROFITABILITAS DI PT. BANK SYARIAH MANDIRI
}

\author{
Ira Siti Rohmah Maulida \\ Universitas Islam Bandung Jl. Ranggagading No. 08 Bandung Jawa Barat Indonesia \\ irasitirohmahmaulida@gmail.com
}

\begin{abstract}
Abstrak
Tujuan dari penelitian ini untuk mengukur pengaruh biaya promosi dan biaya tenaga kerja terhadap profitabilitas. Metode pengumpulan data dengan menganalisi laporan keuangan terkait dengan profitabilitas, biaya promosi serta biaya tenaga kerja periode 2011 sampai 2015. Model analisis data yang digunakan adalah analisis regresi liner berganda. Pengujian hipotesis secara simultan maupun parsial dilakukan dengan menggunakan sofware eviews 7 . Hasil penelitian menunjukan bahwa pengaruh biaya promosi serta biaya tenaga kerja secara simultan terhadap tingkat profitabilitas, diketahui bahwa Kemudian Nilai R-Square sebesar 0.677358 menunjukkan bahwa proporsi pengaruh variabel Biaya Promosi (X1) dan Biaya Tenaga Kerja (X2) terhadap Profitabilitas (ROA) Bank Syariah Mandiri sebesar 67,73\%, sedangkan sisanya sebesar $32,27 \%$ dipengaruhi faktor lain yang tidak diteliti dalam pembahasan ini.
\end{abstract}

Kata Kunci : Biaya Promosi, Biaya Tenaga Kerja, Profitabilitas

\begin{abstract}
The purpose of this study is to measure the effect of promotion costs and labor costs on profitability. Data collection method is done by analyzing financial statements related to profitability, promotion cost and labor cost period 2011 to 2015. Data analysis model used is multiple linear regression analysis. Hypothesis testing simultaneously or partially done by using software eviews 7. The results showed that the influence of promotion costs and labor costs simultaneously to the level of profitability, it is known that Then R-Square value of 0.677358 indicates that the proportion of influence of Promotion Cost (X1) and Labor Cost (X2) to Profitability (ROA) of Bank Syariah Mandiri of $67.73 \%$, while the rest of $32.27 \%$ influenced other factors not examined in this discussion.
\end{abstract}

Keyword: Campaign Costs, Labor Costs, Profitability

\section{PENDAHULUAN}

Analisis efisiensi biaya sangat diperlukan dan perlu diketahui konponen efiseinsi atau tidaknya operasional bank tersebut. (Rahmawati, 2015) Tujuan utama operasional bank adalah mencapai laba bersih yang maksimal. (Arifin, 2012)

Penilaian kinerja keuangan perbankan dapat digunakan untuk mengetahui seberapa besar keuntungan bank dengan membandingkan hasil laba pada tahun

Received: 2018-11-09 | Reviced: 2019-01-29 | Accepted: 2019-02-08

Indexed : DOAJ, Garuda, Crossref, Google Scholar | DOI: https://doi.org/10.29313/amwaluna.v3i1.4180 
Ira SIti Rohmah : Pengaruh Biaya Promosi dan Biaya Tenaga Kerja Terhadap Profitabilitas di BNI

tertentu dengan laba tahun-tahun sebelum dan sesudahnya. (Antonio, 2001)

Salah satu cara untuk melihat pertumbuhan ekonomi perusahaan yaitu adanya Laporan keuangan, dimana laporan keuangan merupakan salah satu sumber informasi mengenai kondisi dan kinerja suatu perusahaan bagi pihak eksternal. Informasi tersebut menyangkut posisi keuangan, kinerja serta perubahan posisi keuangan suatu perusahaan, dan bermanfaat bagi sejumlah besar pemakai dalam pengambilan keputusan ekonomi. ( Sudarmadji \& Sularto, 2007)

Tingkat profitabilitas yang tinggi menunjukkan tingkat efisiensi perusahaan. Profit/keuntungan yang diperoleh tidak saja digunakan untuk membiayai operasi perusahaan, akan tetapi juga digunakan untuk ekspansi perusahaan melalui berbagai kegiatan di masa yang akan datang. Kemudian yang lebih penting lagi apabila suatu badan usaha terus-menerus memperoleh keuntungan maka ini berarti kelangsungan hidup badan usaha tersebut akan terjamin. Sebagai suatu sistem yang berorientasi pada profitabilitas, hal ini menjadi faktor pendorong bagi suatu perusahaan untuk mendapatkan revenue yang diperoleh dari selisih antara harga pokok produksi dengan nilai jual produk/jasanya (Hidayat \& Suhandi, 2013)
Melihat fenomena yang ada bahawasannya konsumen memerlukan promosi untuk menentukan keputusan suatu produk yang akan dibeli. Promosi merupakan salah satu faktor yang membantu keberhasilan suatu perusahaan dalam kegiatan pemasarannya, namun belum menjamin keberhasilan pemasaran terhadap produk. (Dalfa, Tresnati, \& Srisusilawati, 2018)

Berdasarkan pengamatan awal yang dilakukan pada laporan keuangan Bank Umum Syariah maka dapat menjadi contoh yaitu Bank Syariah Mandiri yang di publikaskan ternyata tingkat biaya promosi juga berpengaruh secara positif terhadap profitabilitas perusahaan karena dengan bertambahnya biaya promosi merupakan efek positif dari tingginya tingkat penjualan produk sehingga bisa meningkatkan profitabilitas perusahaan. Namun di Bank Syariah Mandiri biaya promosi berpengaruh negatif terhadap laba perusahaan. Pada Bank Syariah Mandiri terjadi pada tahun 2015 per 30 September.

Tabel 1.1

Biaya Promosi PT. Bank Syariah Mandiri 2011-2015

(Per triwulan)

Dalam Jutaan Rupiah

\begin{tabular}{|c|c|c|c|c|c|}
\hline \multirow{2}{*}{ Triwulan } & \multicolumn{5}{|c|}{ Tahun } \\
\hline & 2011 & 2012 & 2013 & 2014 & 2015 \\
\hline$I$ & 13,810 & 23,202 & 12,534 & 7,798 & 10,599 \\
\hline II & 45,568 & 37,732 & 28,953 & 17,978 & 35,555 \\
\hline III & 70,909 & 64,351 & 54,775 & 38,855 & 47,547 \\
\hline IV & 108,094 & 个 107,456 & 81,185 & 55,512 & 56,187 \\
\hline rand Total & 238,381 & $\nabla 232,741$ & $\nabla 177,447$ & $\nabla 120,143$ & $\nabla 149,888$ \\
\hline
\end{tabular}

Sumber: (laporan keuangan bank syariah) 
Dari tabel tersebut biaya promosi Bank Syariah Mandiri pada tahun 2015 triwulan tiga ada dalam kondisi tinggi sebesar Rp. 47.547.000.000, akan tetapi laba pada tahun tersebut menunjukan penurunan sebesar Rp. 205.797.000.000 yaitu:

Tabel 1.2

Profitabilitas PT. Bank Syariah Mandiri 2011-2015

(Per triwulan)

Dalam Jutaan Rupiah

\begin{tabular}{|c|c|c|c|c|c|c|c|c|c|}
\hline \multirow{2}{*}{ Triwulan } & \multicolumn{9}{|c|}{ Tahun } \\
\hline & 2011 & & 2012 & & 2013 & & 2014 & & 2015 \\
\hline 1 & 184,271 & in & 257,260 & is & 342,615 & 10 & 270,404 & $\Omega$ & 125,577 \\
\hline 11 & 360,454 & $\underline{1}$ & 529,399 & is & 487,600 & $\sqrt{3}$ & 203,025 & र & 180,356 \\
\hline III & 548,594 & & 789,061 & 1 & 629,908 & 10 & 369,279 & $\overline{1}$ & 205,797 \\
\hline IV & 741,645 & 1 & $1,097,133$ & 1 & 874,903 & n & 96,120 & 1 & 360,322 \\
\hline Grand Total & $1,834,964$ & $\Delta$ & $2,672,853$ & $\Delta$ & $2,335,026$ & 穴 & 938,828 & 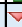 & 872,052 \\
\hline
\end{tabular}

Sumber: (laporan keuangan bank syariah)

Beban operasional di bank syariah saat ini masih tinggi dibandingkan dengan bank konvensional menurut Deputi Komisioner Departemen Manajemen Strategi Edukasi 1B OJK Lucky Hadibrata mengatakan BOPO perbankan syariah masih tinggi karena kelompok ini baru beroperasi (Hana, Neneng. 2016). Berdasarkan data Statistik Perbankan Indonesia (SPI) yang dipublikasikan OJK, pada Mei 2014, BOPO bank syariah berada pada level $84,50 \%$. Sementara pada periode yang sama, BOPO perbankan konvensional tercatat sebesar 76,20\%. Menurut Lucky, besaran BOPO tersebut masih wajar mengingat perbankan syariah kini tengah melakukan investasi besar-besaran untuk mendirikan kantor, infrastruktur, dan penyediaan sumber daya manusia (SDM). "Mereka fokus ke situ, jadi tinggi." Sebagaimana di gambarkan dalam tabel untuk biaya tenaga kerja bank syariah mandiri yang menjadi contoh.

Tabel 1.3

\section{Biaya Tenaga Kerja PT. Bank Syariah Mandiri 2011-2015 \\ (Per triwulan) \\ Dalam Jutaan Rupiah}

\begin{tabular}{|c|c|c|c|c|c|c|c|}
\hline \multirow{2}{*}{ Triwulan } & \multicolumn{7}{|c|}{ Tahun } \\
\hline & 2011 & 2012 & & 2013 & & 2014 & 2015 \\
\hline 1 & 204,380 & 271,925 & $\sqrt{3}$ & 270,407 & 1 & 343,346 & 379,704 \\
\hline II & 422,335 & 489,702 & 1 & 589,551 & 10 & 820,690 & 966,425 \\
\hline III & 667,043 & 706,720 & 个 & 928,550 & 步 & 38,855 & 47,547 \\
\hline IV & 964,882 & 973,160 & 个 & $1,192,403$ & 11 & $1,359,776$ & $1,685,208$ \\
\hline Grand Total & $2,258,640$ & $\Delta 2,441,507$ & $\Delta$ & $2,980,911$ & $\nabla$ & $2,562,667$ & $\Delta \quad 3,078,884$ \\
\hline
\end{tabular}

Sumber: (laporan keuangan bank syariah)

Melihat pada tabel tersebut bahwasannya biaya tenaga kerja khususnya di triwulan 1,2, dan 4 mengalami kenaikan yang signifikan. Untuk di triwulan tiga tahun 2014 dan tahun 2015 mengalami penurunan secara drastis karena melihat laba di pada periode tersebut pun menurun. Dari fenomena di atas biaya promosi dan biaya tenga kerja akan mempengaruhi profitabilitas. Ketika keduanya mengalami kenaikan atau penurunan akan mengalami perubahan. Masalah tersebut, tentu saja, dipengaruhi oleh banyak faktor di PT. Bank Syariah Mandiri, menurut dugaan peneliti terdapat ada dua faktor yang sangat menentukan. Kedua faktor tersebut adalah:

1. Faktor Biaya Promosi, karena dalam kenyataannya memperlihatkan kecenderungan-kecenderungan salah satunya ketika biaya promosi menaik seharusnya dapat berpengaruh yang positif terhadap profitabilitas.

2. Faktor tenaga kerja, karena dalam kenyataannya memperlihatkan 
Ira SIti Rohmah : Pengaruh Biaya Promosi dan Biaya Tenaga Kerja Terhadap Profitabilitas di BNI

berpengaruh terhadap kinerja dan kesejahteraan ketika gaji tenaga kerja menaik tapi pada kenyataannya sedikit pengaruh terhadap tenaga kerja menurut pengamatan awal peneliti.

Berdasarkan latar belakang masalah di atas, maka Identifikasi masalahnya adalah:

1. Seberapa besar pengaruh biaya promosi terhadap profitabilitas (ROA) pada periode 2011-2015 di PT. Bank Syariah Mandiri,

2. Seberapa besar pengaruh biaya tenaga kerja terhadap profitabilitas (ROA) pada periode 2011-2015 di PT. Bank Syariah Mandiri, 3. Seberapa besar pengaruh biaya promosi, dan biaya tenaga kerja terhadap profitabilitas pada periode 2011-2015 di PT. Bank Syariah Mandiri. Berdasarkan pada rumusan masalah di atas, maka tujuan penelitian adalah Menganalisis dan menguji pengaruh biaya promosi terhadap profitabilitas pada periode 2011-2015 di PT. Bank Syariah Mandiri, Menganalisis dan menguji pengaruh biaya tenaga kerja terhadap profitabilitas pada periode 20112015 di PT. Bank Syariah Mandiri, Menganalisis dan menguji pengaruh pendapatan operasioanal, biaya promosi, dan biaya tenga kerja secara bersamaan terhadap profitabilitas pada periode 20112015 di PT. Bank Syariah Mandiri. Dalam penelitian ini menggunakan Metode pengumpulan data dilakukan dengan menganalisi laporan keuangan terkait dengan profitabilitas, biaya promosi serta biaya tenaga kerja periode 2011 sampai 2015. Model analisis data yang digunakan adalah analisis regresi liner berganda. Pengujian hipotesis secara simultan maupun parsial dilakukan dengan menggunakan sofware eviews 7.

\section{PEMBAHASAN}

\section{A. Literature Review}

Produk sudah diciptakan, harga sudah ditetapkan, dan tempat (lokasi dan layout sudah disediakan), artinya produk sudah benar-benar siap untuk dijual. Agar produk tersebut laku dijual ke masyarakat atau nasabah, maka masyarakat perlu tahu kehadiran produk tersebut berikut manfaat, harga, di mana bisa diperoleh, dan kelebihan-kelebihannya di bandingkan produk pesaing. Cara untuk memberitahukan kepada masyarakat adalah melalui sarana promosi. Artinya, keputusan terakhir bank harus mempromosikan produk tersebut seluas mungkin ke nasabah. (Antonio, 2001)

Promosi berfungsi memberi tahu, mengajak dan mempengaruhi proses pengambilan keputusan pelanggan. Pada umumnya, manajer pemasaran bank akan bereaksi terhadap sasaran dan tujuan bank dengan merumuskan berbagai bauran 
promosi, yaitu personal selling /merchandising service (layanan promosi niaga/wiraniaga), iklan (advertising), promosi penjualan (sales promotion), public relation, dan publisitas. Promotional mix merupakan transmisi pesan komunikasi antara bank dan pelanggan potensial untuk membentuk hubungan transaksi (Ali Hasan. 2010) (Srisusilawati, 2017).

Setiap aktivitas yang diperlukan dalam proses produksi barang atau jasa pada perusahaan memunculkan pengorbanan untuk pengadaan seluruh sumber daya yang diperlukan. Pengorbanan tersebut tentu akan memunculkan tanggung jawab bagi perusahaan, yang biasa dikenal dengan istilah 'biaya' (Hidayat \& Suhandi, 2013)

Pemahaman terhadap konsep biaya sangatlah penting karena biaya merupakan salah satu faktor yang dapat menentukan besar kecilnya laba bagi perusahaan di samping komponen lainnya, yaitu pendapatan. Bagi perusahaan, adanya pengklasifikasian biaya dapat memudahkan proses pencatatan dan membantu menggambarkan informasi yang tepat atas berbagai biaya yang dikeluarkan oleh berbagai pihak dalam perusahaan untuk berbagai kepentingan. (Hidayat \& Suhandi, 2013)

Penggolongan biaya ini dilakukan dengan berbagai cara yang berbeda sesuai dengan kebutuhan dari masing-masing perusahaan.

"Biaya tenaga kerja mewakili kontribusi manusia dalam proses produksi, dan dalam sistem akuntansi biaya tenaga kerja ini sangat dibutuhkan pengukuran yang ajeg, pengendalian, dan analisis" (Kuncoro, 2002)

Biaya tenaga kerja diartikan sebagai suatu balas jasa yang diberikan sebagai pengganti tenaga kerja orang yang menjual tenaganya yang pada umumnya berupa uang atau sesuatu yang dapat dinilai dengan uang. Sedangkan komponen atas biaya tersebut dapat dibedakan menjadi dua bagian, yaitu: (a) Biaya gaji, dan (b) Biaya upah. Biaya gaji dan upah dalam perusahaan harus mendapatkan perhatian yang seksama dan teliti, karena hal tersebut dapat mempengaruhi secara langsung prestasi yang diberikan oleh pekerja kepada perusahaan, juga berpengaruh terhadap semangat kerja para karyawan (Setiawan, 2013)

Upah adalah suatu jumlah pembayaran kepada tiap-tiap pegawai, baik sebagai alat identifikasi maupun sebagai alat pemeriksaan terhadap penggelapan. (Moekijat, 2008)

Ahli ekonomi lain mengatakan bahwa upah adalah balas jasa yang diberikan kepada pegawai baik upah per jam, upah per hari, upah per minggu maupun upah per 
Ira SIti Rohmah : Pengaruh Biaya Promosi dan Biaya Tenaga Kerja Terhadap Profitabilitas di BNI

bulan yang diberikan tergantung dari kegiatan pekerja (Ibrahim, 2013)

Rasio Profitabilitas (Profitability Ratios) adalah sekelompok rasio yang menunjukkan kombinasi dan pengaruh likuiditas, manajemen aset, dan utang pada hasil operasi (Brigham dan Joel F). Rasio profitabilitas adalah rasio yang menunjukkan efektifitas menciptakan laba. Laba pada dasarnya menunjukkan seberapa baik perusahaan dalam membuat keputusan investasi dan pembiayaan. (Tampubolon, 2005) Tujuan utama dari operasi perusahaan jasa adalah untuk menghasikan laba.

Profitabilitas adalah kemampuan bank untuk memperoleh keuntungan. Hal ini terlihat pada perhitungan tingkat produktifitasnya, yang ditunjukan dalam rumus ROA (Return On Assets). Jika kredit tidak lancar, maka profitabilitasnya menjadi kecil. ROA mengandung dua elemen yaitu elemen yang dapat dikontrol dan elemen yang tidak dapat dikontrol.

\section{Indikator Profitabilitas}

Untuk mengukur kemampuan bank memperoleh keuntungan dapat mengunakan rasio profitabilitas tergantung pada informasi yang diambil dari laporan keuangan. Rasio profitabilitas merupakan gambaran kemampuan perusahaan untuk mendapatkan laba. Rasio profitabilitas terdiri dari :(Hidayat \& Suhandi, 2013)
a. Margin laba (Profit Margin)
b. Return On Investment (ROI)
c. Return On Asset (ROA)
d. Return on Equity (ROE)

\section{B. Hasil Penelitian}

\section{Pengaruh Biaya Promosi Secara Parsial Terhadap Profitabilitas (ROA)}

Hipotesis alternatif pertama dalam penelitian ini seperti yang sudah disebutkan dalam bab tiga yaitu Biaya Promosi berpengaruh positif dan signifikan terhadap Profitabilita ROA di Bank Syariah Mandiri. Hipotesis tersebut diuji secara kuantitatif yang dalam pengolahan datanya dilakukan denganbantuan program Eviews 7. Dengan melakukan analisis regresi berganda oleh variabel bebas terhadap variabel dependen.Untuk menguji hipotesis dari pengaruh variabel bebas terhadap variabel terikat secara parsial dilakukan dengan menggunakan uji t dan uji signifikansi terhadap nilai probabilitas $0,05(5 \%)$.

Dari tabel di atas, menunjukan nilai dari koefisien variabel Biaya Promosi (X1) adalah sebesar 8.023421. Koefisien tersebut menunjukan nilai positif yang mengandung arti bahwa hubungan antara variabel Biaya Promosi (X1) dan variabel ROA adalah searah. Ketika terjadi kenaikan Biaya Promosi (X1) sebesar satu poin, maka akan diikuti oleh kenaikan ROA sebesar 
8.023421 atau 8,02\%.begitu juga

Sebaliknya ketika ada penurunan Biaya Promosi (X1) sebesar satu poin, maka akan diikuti juga oleh penurunan ROA sebesar 8.023421 atau $8,02 \%$.

Kemudian Hasil dari perhitungan dengan menggunakan uji $\mathrm{t}$ dan tingkat signifikansi dengan memperhatikan nilai probabilitasnya sama-sama menerima hipotesis alternatif. Berdasarkan uji hipotesis tersebut dapat dinyatakan bahwa Nilai prob. t hitung dari variabel bebas Biaya Promosi (X1) sebesar 0.0000 yang lebih kecil dari 0,05 artinya berpengaruh signifikan terhadap variabel terikat ROA pada alpha 5\% atau dengan kata lain, Biaya Promosi (X1) berpengaruh positif dan signifikan terhadap Profitabilitas ROA di Bank Syariah Mandiri.

Hal tersebut menyatakan bahwa biaya promosi yang dilakukan Bank Syariah Mandiri sudah terarah. Artinya Bank Syariah Mandiri sudah bisa menekan atau menggunakan biaya promosi secara efektip dan efesien. Jika kegiatan ini terus dilakukan, maka perusahaan, dalam hal ini Bank Syariah Mandiri akan terus mengalami peningkatan penjualan, dengan penjualan yang terus meningkat maka akan meningkatkan Profitabilitas (ROA) di Bank Syariah Mandiri.

Hasil penelitian ini sekaligus mendukung teori dan konsep yang dikemukakan oleh Harnanto dan Zulkifli biaya adalah segala sesuatu yang harus dikorbankan dengan tujuan akhir yaitu mendatangkan laba (Harnanto dan Zulkifli. 2013). Semakin tinggi biaya promosi maka akan meningkatkan profitabilitas (ROA). Pemasaran adalah salah satu kegiatan pokok yang perlu dilakukan oleh perusahaan baik itu perusahaan dagang atau perusahaan barang dalam upaya meningkatkan penjualan. Promosi adalah teknik-teknik mengomunikasikan suatu produk yang digunakan oleh perusahaan untuk berinteraksi dengan target pasar mereka dan khalayak ramai. Tujuan promosi adalah untuk meningkatkan penjualan dan keuntungan.

Kemudian penelitian ini juga memperkuat teori yang dikemukakan (Nurlaelah \& Falah, 2017) bahwa salah satu jalan untuk menarik dan meningkatkan volume penjualan adalah promosi. Setelah masyarakat mengenal, mengetahui barang yang dipromosikan, maka diharapkan mereka mau mencoba membelinya. Dengan demikian tujuan perusahaan untuk menaikkan jumlah penjualan kemungkinan besar akan tercapai sehingga akan meningkatkan laba perusahaan.

\section{Pengaruh Biaya Tenaga Kerja Secara Parsial Terhadap Profitabilitas (ROA)}


Ira SIti Rohmah : Pengaruh Biaya Promosi dan Biaya Tenaga Kerja Terhadap Profitabilitas di BNI

Setelah melakukan pembahasan secara parsial variabel Biaya Promosi (X1), maka selanjutnya akan dilakukan pembahasan pengaruh variabel bebas kedua yaitu Biaya Tenaga Kerja (X2) terhadap Profitabilitas (ROA).

Dependent Variable: ROA

Method: Least Squares

Date: 04/25/17 Time: $16: 47$

Sample: 2011Q1 2015Q4

Included observations: 20 probabilitasnya sama-sama menerima hipotesis alternatif. Berdasarkan uji hipotesis tersebut dapat dinyatakan bahwa Nilai prob. t hitung dari variabel bebas Biaya Tenaga Kerja (X2) sebesar 0.1193 yang lebih besar dari 0,05 artinya tidak berpengaruh signifikan terhadap variabel terikat ROA pada alpha 5\% atau dengan kata lain, Biaya Tenaga Kerja (X2) tidak berpengaruh signifikan dan nilainya negatif

\begin{tabular}{lrrrr}
\hline \multicolumn{1}{c}{ Variable } & Coefficient & Std. Error & t-Statistic \\
\hline \hline BIAYA_PROMOSI & 8.023421 & 1.348570 & 5.949575 \\
TENAGA_KERJA & -0.387609 & 0.236283 & -1.640442 \\
C & 81.59394 & 72.08034 & 1.131986 \\
\hline \hline R-squared & 0.677358 & Mean dependent var \\
Adjusted R- & & & \\
squared & 0.639401 & S.D. dependent var \\
S.E. of & & & \\
regression & 171.7023 & Akaike info criterion \\
Sum squared & & & \\
resid & 501188.7 & Schwarz criterion \\
Log likelihood & -129.6688 & Hannan-Quinn criter. \\
F-statistic & 17.84503 & Durbin-Watson stat \\
Prob(F-statistic) & 0.000067 & \\
\hline \hline
\end{tabular}

Dari tabel di atas, menunjukan nilai dari koefisien variabel Biaya Tenaga Kerja (X2) adalah sebesar -0.387609 . Koefisien tersebut menunjukan nilai negatif yang mengandung arti bahwa hubungan antara variabel Biaya Tenaga Kerja (X2) dan variabel ROA adalah berlawanan. Ketika terjadi kenaikan Biaya Tenaga Kerja (X2) sebesar satu poin, maka akan diikuti oleh penurunan ROA sebesar -0.387609 atau $0,38 \%$.

Kemudian Hasil dari perhitungan dengan menggunakan uji $\mathrm{t}$ dan tingkat signifikansi dengan memperhatikan nilai
Prob!erhadap Profitabilitas ROA di Bank 0\$19 Mandiah Artinya setiap 0 pepfingkatan biaya tenaga kerja akan 424.1631
mengkibatkan menurunya tingkat 285.9326 profitabilitas (ROA) di Bank Syariah 13.26688 Mandiri.

13.41624

13.29604 Hasil Analisis penelitian ini 0.822727
sekaligus menolak penelitian sebelumnya yang dilakukan oleh Nugroho (Nugroho. 2012) dan Penelitian yang dilakukan oleh (Pratiwi. 2012) yang menyimpulkan bahwa Operational Cost Ratio to Operational Income (BOPO) secara parsial berpengaruh signifikan terhadap Return On Asset (ROA) pada Bank Umum Swasta Nasional Devisa periode 2007-2011 pada level of signifikan $5 \%$.

\section{Pengaruh Biaya Promosi dan Biaya Tenaga Kerja Secar Simultan Terhadap Profitabilitas (ROA)}

Data yang digunakan dalam penelitian ini adalah data sekunder. Oleh sebab itu, untuk menentukan ketepatan model regresi 
berganda yang dihasilkan harus melewati pengujian atas beberapa asumsi klasik. pengujian yang akan digunakan yaitu:

Uji Normalitas, Multikolinieritas, Heteroskedastisitas, dan Autokorelasi Dari hasil semua uji diatas menyimpulkan bahwa penelitian ini terbebas dari permasalahan asumsi klasik. Dengan begitu, model regresi berganda yang dihasilkan dapat digunakan sebagai estimator yang baik bagi penentuan kesimpulan penelitian. Begitu juga dengan bebasnya dari asumsi klasik membuat hasil uji hipotesis yang lebih akurat. Setelah lulus dari uji asumsi klasik, maka selanjutnya dilakukan analisis regresi berganda terhadap data-data penelitian yang dihasilkan.

Hasil uji $\mathrm{F}$ dapat dilihat pada tabel di atas. Nilai prob. F (Statistic) sebesar 0.000067 lebih kecil dari tingkat signifikansi 0,05 sehingga dapat disimpulkan bahwa model regresi yang diestimasi layak digunakan untuk menjelaskan pengaruh Biaya Promosi (X1) dan Biaya Tenaga Kerja (X2) terhadap Profitabilitas (ROA).

Kemudian Nilai R-Square pada tabel di atas besarnya 0.677358 menunjukkan bahwa proporsi pengaruh variabel Biaya Promosi (X1) dan Biaya Tenaga Kerja (X2) terhadap Profitabilitas (ROA) sebesar 67,73\%. Artinya Biaya Promosi (X1) dan
Biaya Tenaga Kerja (X2) memiliki proporsi pengaruh terhadap Profitabilitas (ROA). sebesar $67,73 \%$.

Profitabilitas adalah kemampuan perusahaan untuk memperoleh laba dengan menggunakan sejumlah modal tertentu. Profitabilitas atau kemampuan memperoleh laba adalah suatu ukuran dalam presentase yang digunakan untuk menilai sejauh mana perusahaan mampu menghasilkan laba pada tingkat yang dapat diterima. Angka profitabilitas dinyatakan antara lain dalam angka laba sebelum atau sesudah pajak, laba investasi, pendapatan per saham, dan laba penjualan. Nilai profitabilitas menjadi norma ukuran bagi kesehatan perusahaan.

Profitabilitas diukur dengan beberapa rasio dan salah satunya adalah rasio ROA yang mengukur kemampuan manajemen dalam memperoleh keuntungan secara relatif dibandingkan dengan total assetnya atau ukuran untuk menilai seberapa besar tingkat pengembalian dari aset perusahaan. Pihak - pihak yang berkepentingan untuk mengetahui tingkat profitabilitas adalah masyarakat, pemegang saham, pemerintah, dan manajemen bank ( Sudarmadji \& Sularto, 2007)

Masyarakat berkepentingan untuk mengetahui tingkat profitabilitas bank karena bank merupakan suatu lembaga keuangan yang dipercayakan masyarakat untuk menyimpan dananya dan terjamin 
Ira SIti Rohmah : Pengaruh Biaya Promosi dan Biaya Tenaga Kerja Terhadap Profitabilitas di BNI

akan kerahasiaannya. Oleh karena itu, dalam rangka melindungi kepentingan para peminjam dana di suatu bank, maka pemerintah melalui Bank Indonesia mewajibkan setiap bank untuk mengumumkan perhitungan laba ruginya di media cetak. Dengan diumumkannya neraca dan laporan keuangan lainnya di media cetak secara meluas, maka bonafiditas dari bank-bank yang bersangkutan dapat diketahui dengan mudah, hingga dengan demikian seorang calon debitur akan memilih bank mana yang akan membiayai proyeknya.

Untuk kepentingan pemegang saham, sebagian bank-bank di Indonesia pada saat ini dimiliki oleh kelompok yang terbatas antara lain pemerintah pusat, pemerintah daerah dan sekelompok individu pengusaha dan setelah itu segelintir bank yang go public. Sehingga kepentingan para pemilik disini belum dapat diukur dengan jumlah deviden yang akan ia terima dari sahamsaham yang dimilikinya, tetapi penilaiannya banyak terbatas apakah manjemen yang mengelola bank-bank tersebut telah sukses atau tidak.

Tingkat profitabilitas bagi pemerintah dalam hal perpajakan dimaksudkan agar dengan mempelajari laporan-laporan keuangan yang telah diumumkan maka pihak pajak akan dapat lebih mudah menjalankan tugasnya dalam menetapkan besarnya pajak perseroan bagi bank yang bersangkutan. Untuk kepentingan manajemen bank sendiri yaitu dalam mengelola bank yang bersangkutan, para pejabat bank perlu mengatur posisi likuiditasnya. Berapa besar tingkat likuiditas yang perlu dipertahankan agar tetap bisa beroperasi dan dapat mempertahankan tingkat profitabilitasnya.

ROA digunakan untuk mengukur profitabilitas bank karena Bank Indonesia sebagai pembina dan pengawas perbankan lebih mengutamakan nilai profitabilitas suatu bank, diukur dengan aset yang dananya sebagian besar dari dana simpanan masyarakat. Semakin besar ROA suatu bank, semakin besar pula tingkat keuntungan yang dicapai bank, dan semakin baik pula posisi bank dari segi penggunaan asset.. ROA dirumuskan sebagai berikut (Dendawijaya. 2012) :

$$
\begin{aligned}
\text { Rumus } & \text { ROA } \\
& =\underline{\text { Laba Bersih }} \mathrm{X} \\
& 100 \% \\
& \text { Total Aktiva }
\end{aligned}
$$

Elemen ROA yang dapat dikontrol meliputi : bauran bisnis, penciptaan laba, kualitas kredit dan pengeluran biaya. Sedangkan elemen yang tidak dapat dikontrol merupakan elemen di luar lingkungan perusahaan, seperti gejala perekonomian, perubahaan peraturan pemerintah, berubahnya selera konsumen, 
perubahan teknologi, dan sebagainya (Darmawi, 2012)

Rasio profitabilitas menggambarkan kemampuan bank dalam meningkatkan labanya melalui semua kemampuan dan sumber yang ada sehingga diketahui untuk mengukur tingkat efisiensi usaha dan keuntungan yang dicapai oleh bank tersebut (Arifin, 2012)Tingkat kesehatan bank yang dapat digunakan untuk mengukur kemampuan bank dalam memperoleh keuntungan adalah profitabilitas bank. Profitabilitas merupakan kemampuan perusahaan untuk menghasilkan suatu pendapatan atau laba.

Penelitian ini sejalan dengan yang dilakukan oleh Penelitian yang dilakukan oleh (Adyani, 2011) yang bertujuan untuk menguji pengaruh variabel Capital Adequacy Ratio (CAR), Non Performing Financing (NPF), Biaya Operasional Pendapatan Operasional (BOPO), dan Financing to Deposit Ratio (FDR) terhadap Profitabilitas (ROA). Dengan menggunakan metode penelitian kuantitatif dengan jenis sampel purpose sampling serta dari hasil penelitian secara simultan (uji F) menyatakan bahwa CAR, NPF, BOPO, dan FDR secara bersama-sama berpengaruh terhadap profitabilitas (ROA) bank. Sedangkan hasil koefisien determinasi menunjukkan bahwa korelasi antara profitabilitas (ROA) bank dengan 4 variabel bebas sebesar $45,2 \%$. Serta hasil dari penelitian secara parsial (uji t) menyatakan bahwa variabel CAR dan FDR tidak berpengaruh signifikan positif terhadap profitabilitas (ROA) bank. Variabel NPF dan BOPO berpengaruh negatif signifikan terhadap profitabilitas (ROA) bank.

Kedua variabel biaya promosi, biaya tenaga kerja bersama-sama berpengaruh signifikan terhadap ROA. Hal ini menunjukkan bahwa jika terjadi efisiensi pengeloaan biaya promosi serta biaya tenaga kerja maka akan meningkatkan profitabilitas (ROA), atau biaya promosi dan biaya tenaga kerja yang efisien dan tepat sasaran diharapkan bisa menarik nasabah untuk melakukan investasi yang sebesar-besarnya sehingga pihak bank juga bisa memberikan pembiayaan yang leluasa kepada pihak nasabah yang mengajukan pembiayaan, maka secara tidak langsung akan meningkatkan profitabilitas bank itu sendiri.

\section{SIMPULAN}

\section{A. Simpulan}

Setelah melakukan analisis terhadap hipotesis yang diuji dalam penelitian ini, maka dapat ditarik beberapa kesimpulan sebagai berikut: (1)Biaya Promosi (X1) secara parsial memiliki pengaruh positif dan signifikan terhadap tingkat 
profitabilitas di Bank Syariah Mandiri. (2)Biaya Tenaga Kerja (X2) secara parsial berpengaruh negatif dan tidak signifikan terhadap Profitabilitas (ROA). (3)Biaya promosi dan biaya tenaga kerja secara simultan memiliki pengaruh positif dan signifikan terhadap tingkat profitabilitas di Bank Syariah Mandiri.

\section{B. Saran}

Berdasarkan kesimpulan diatas, terdapat saran untuk Peningkatan Profitabilitas (ROA) Bank Syariah Mandiri dimasa yang akan datang yaitu: (1)Bank Syariah Mandiri diharapkan dapat mengefisiensikan biaya operasional khususnya Biaya Promosi dan Biaya tenaga Kerja dengan menghemat pengeluaran dan harus lebih meningkatkan pembiayaan sehingga dapat memperoleh keuntungan yang meningkat dari tahun ke tahun. (2)Untuk Bank Syariah Mandiri khususnya penelitian ini diharapkan dapat memberikan gambaran masukan mengenai pengaruh efisiensi pengeloaan pembiayaan dan tingkat kecukupan modal terhadap tingkat profitabilitas sehingga divisi pembiayaan khususnya bisa lebih efisien dalam mengelola pembiayaan sehingga penyaluran pembiayaan kepada nasabah bisa efisien dan tepat sasaran dan menghindari pembiayaan bermasalah, sehingga apabila profitabilitas perusahaan meningkat maka kepercayaan masyarakat atau nasabah menjadi meningkat.

\section{DAFTAR PUSTAKA}

Sudarmadji, A. M., \& Sularto, 1. (2007). Pengaruh ukuran perusahaan, profitabilitas, leverage, dan tipe kepemilikan perusahaan terhadap luas voluntary disclosure laporan keuangan tahunan. Seminar Ilmiah Nasional PESAT. Lembaga Penelitian Univers.

Adyani, L. R. (2011). Analisis faktor-faktor yang mempengaruhi profitabilitas (ROA). Skripsi. Universitas Diponegoro.

Antonio, M. S. (2001). Bank Syariah: dari teori ke praktik. Gema Insani.

Arifin, Z. (2012). Dasar-dasar manajemen bank syariah. Pustaka Alvabet.

Dalfa, S., Tresnati, R., \& Srisusilawati, P. (2018). Kajian Bauran Pemasaran Pembiayaan KPR Islamic Banking Menggunakan Analisis Swot (Studi Kasus pada BPRS Al Salaam Cabang Bandung). Prosiding Hukum Ekonomi Syariah, 696-701.

Darmawi, H. (2012). Manajemen Perbankan. jakarta: Bumi Aksara.

Hidayat, L., \& Suhandi, S. (2013). Analisis Biaya Produksi dalam Meningkatkan Profitabilitas Perusahaan. Jurnal Ilmiah Manajemen Kesatuan 1.2, 159-168.

Ibrahim, Z. (2013). HUKUM PENGUPAHAN YANG BERKEADILAN SUBSTANTIF (Kajian Teoritis Terhadap Teori Upah Teladan). Masalah-Masalah Hukum 42.2, 292301.

Kuncoro, H. (2002). Upah Sistem Bagi Hasil dan Penyerapan Tenaga Kerja. Jurnal Ekonomi Pembangunan 7.1, 45-56.

laporan keuangan bank syariah. (n.d.). Retrieved from 
(http://www.syariahmandiri.co.id/categ ory/investor-relation/laporan-triwulan/)

Moekijat. (2008). Administrasi Kantor. Bandung: Alumni.

Nurlaelah, \& Falah, S. (2017). PENGARUH BIAYA PROMOSI TERHADAP NET PROFIT MARGIN (NPM) PADA PERUSAHAAN SUB SEKTOR ASURANSI YANG TERDAFTAR DI BURSA EFEK INDONESIA (BEI). The Asia Pacific Journal Of Management Studies 4.3.

Rahmawati, R. (2015). Strategi peningkatan efisiensi biaya pada bank umum syariah berbasis stochastic frontier approach dan data envelopment analysis. Buletin Ekonomi Moneter dan Perbankan 17.4, 1-24.

Setiawan, A. (2013). PENGARUH DISIPLIN KERJA DAN MOTIVASI TERHADAP KINERJAKARYAWAN PADA RUMAH SAKIT UMUM DAERAH KANJURUHAN MALANG. Jurnal Ilmu Manajemen (JIM) 1.4.

Sistaningrum, W. (2002). Manajemen penjualan produk. Yogyakarta: kanisius.

Srisusilawati, P. (2017). Kajian Komunikasi Pemasaran Terpadu Dalam Mendorong Keputusan Pembelian Jasa Perbankan. AMWALUNA: Jurnal Ekonomi dan Keuangan Syariah 1.1, 1-18. 